Parliamentary Government with a Strong President: The Post-1989 Turkish Experience Author(s): Metin Heper and Menderes Çinar Source: Political Science Quarterly, Vol. 111, No. 3 (Autumn, 1996), pp. 483-503

Published by: The Academy of Political Science

Stable URL: http://www.jstor.org/stable/2151972

Accessed: 31-10-2017 06:47 UTC

\title{
REFERENCES
}

Linked references are available on JSTOR for this article:

http://www.jstor.org/stable/2151972?seq=1\&cid=pdf-reference\#references_tab_contents You may need to $\log$ in to JSTOR to access the linked references.

JSTOR is a not-for-profit service that helps scholars, researchers, and students discover, use, and build upon a wide range of content in a trusted digital archive. We use information technology and tools to increase productivity and facilitate new forms of scholarship. For more information about JSTOR, please contact support@jstor.org.

Your use of the JSTOR archive indicates your acceptance of the Terms \& Conditions of Use, available at http://about.jstor.org/terms

The Academy of Political Science is collaborating with JSTOR to digitize, preserve and extend access to Political Science Quarterly 


\section{Parliamentary Government with a Strong President: The Post-1989 Turkish Experience}

\section{METIN HEPER MENDERES ÇINAR}

In his defense of the virtues of parliamentarianism versus those of presidentialism vis-à-vis political stability, Juan J. Linz has made the assumption that there is a close relationship between the consolidation of democracy, which Linz defines as democracy becoming "the only game in town," and the possibility for an equitable distribution of resources, at least in the intermediate run. According to Linz, democracy as a regime would not come under threat if the losers do not lose too much and if they maintain the hope that in the foreseeable future they may retrieve what they have lost. Linz has argued that parliamentarianism rather than presidentialism makes this more probable, because in contrast to the situation in a presidential system of government, in a parliamentary system, those in power usually have less authority at their disposal and can be more easily removed from power. ${ }^{1}$

This view has come under criticism, ${ }^{2}$ but Linz's detractors have not questioned his basic assumption concerning the significance of a balance between the interests

\footnotetext{
1 Juan J. Linz, "The Perils of Presidentialism," Journal of Democracy 1 (Winter 1990): 51-69; Linz, "The Virtues of Parliamentarism," Journal of Democracy 1 (Fall 1990): 84-91.

2 Donald L. Horowitz, "Comparing Democratic Systems," Journal of Democracy, 1 (Winter 1990): 73-79; Seymour Martin Lipset, "The Centrality of Political Culture," Journal of Democracy 1 (Winter 1990): 80-83.
}

METIN HEPER is chair of the Department of Political Science and Public Administration at Bilkent University, Ankara, Turkey, and a founding member of the Turkish Academy of Sciences. He has most recently coedited a book entitled Politics in the Third Turkish Republic. MENDERES ÇINAR is a Ph.D. candidate at the Department of Political Science and Public Administration at Bilkent University. 
of civil societal groups for the consolidation of democracy. This view overlooks Giovanni Sartori's admonition that democracy has both a horizontal and a vertical dimension; there is a need for political participation and prudent government. ${ }^{3}$ There should be a balance not only between the interests of different societal groups but also a balance between different groups' interests and the long-term interests of community. ${ }^{4}$

Linz and his detractors take it for granted that political actors in the non-AngloAmerican contexts, too, double as state elites, who are concerned with the longterm interests of community. They pay little attention to what Samuel P. Huntington argued close to three decades ago-for the consolidation of democracy there is a need for political institutionalization, that is, the emergence of an autonomous political center with its own values and norms, which when necessary would moderate and redirect the relative power of civil societal groups. ${ }^{5}$

The political institutionalization in this sense has faced obstacles not only in the Third World countries but, at least for some time, even in such continental European countries as France and Germany. Consequently, in France and Germany there has been a resort to mixed constitutions, leading to semi-presidentialism or semiparliamentarianism. Linz has assumed that these latter are "hybrid" regimes, evincing characteristics from both presidentialism and parliamentarianism. ${ }^{6}$ The regimes in such countries as France and Germany have not been varieties of presidentialism or parliamentarism, nor hybrid regimes. They have been qualitatively different from both presidentialism and parliamentarianism, because in these regimes sovereignty was divided between the state elites and political elites. The first set of elites, too, exercised sovereignty in its own name; their authority was not derived from those of the political elites. ${ }^{7}$ The state elites in question had been essentially responsible for the guardianship of the long-term

\footnotetext{
${ }^{3}$ Giovanni Sartori, The Theory of Democracy Revisited, Part One: The Contemporary Debate (Chatham, NJ: Chatham House Publishers, 1987), 131-132.

${ }^{4}$ This point has been overlooked not only by Juan J. Linz and his detractors vis-à-vis the question of the presidentialism versus parliamentarianism but also by the proponents of the "Transitions" project, who have placed emphasis on the skillfulness of political actors to bring about a gradual and controlled regime change. See Guillermo O'Donnell, Philippe C. Schmitter, and Laurence Whitehead, Transitions from Authoritarian Rule (Baltimore: Johns Hopkins University Press, 1986), 4 vols. For an elaboration, see Metin Heper, "Transitions to Democracy Reconsidered: A Historical Perspective," in Dankwart A. Rustow and Kenneth Paul Erickson, eds., Comparative Political Dynamics: Global Research Perspectives (New York: HarperCollins, 1991).

${ }^{5}$ Samuel P. Huntington, Political Order in Changing Societies (New Haven: Yale University Press, 1968).

${ }^{6}$ Linz, "The Virtues of Parliamentarism," 85.

${ }^{7}$ The idea of "mixed" constitutions goes back to Aristotle. Closer to our time, Montesquieu denounced despotism and preferred a constitutional monarchy, that is, a mixture of the republican and monarchial forms. See Robert Anchor, The Enlightenment Tradition (Berkeley: University of California Press, 1967), 43-50. An historical example is the "constitutional dualism" of the Bismarckian Reich of the late nineteenth century that combined a concession to the democratic norm with a commitment to the monarchical principle. See Gordon Smith, Democracy in Western Germany: Parties and Politics in the Federal Republic (London: Heineman, 1979), 10.
} 
interests of community and accountable to the people as a collectivity, whereas the political elites have been basically responsible for representing particular interests and accountable to their disparate constituencies. For instance, Charles de Gaulle in France spoke of himself as being "above political struggles, a national arbiter," and called himself ". . . guide of France," entrusted with the destiny of France and that of the republic; he wanted to become "the source of all power." Germans came up with a "chancellor democracy." The chancellor alone was responsible for the general lines of government policy. Ministers tended to be valued for their technical competence and were responsible to the chancellor, not to the parliament. The chancellor could be removed from office only by a constructive vote of no confidence and was expected to stay in office for a full term. ${ }^{9}$

In both France and Germany, at least from World War II onward, democracy has been "the only game in town," yet for some time their political regimes continued to have both "democratic" and "undemocratic" dimensions. The political regimes in these countries had undemocratic dimensions in the sense that those saddled with the responsibility of looking after the long-term interests of community had not considered themselves politically accountable at least in the accomplishment of this particular task of theirs. One example was de Gaulle who wanted to see himself as the source of all power in the French polity. The problem in these regimes had not been the reconciliation of particular interests in an equitable manner but that of bringing about an harmonious relationship between the state and political elites.

In both France and Germany, however, gradually the state and political elites developed essentially an harmonious relationship between themselves even during the period of cohabitation, ${ }^{10}$ basically because in both countries the need to graft an "undemocratic" dimension to their political regimes was recognized by all. ${ }^{11}$ Particularly in the post-de Gaulle France and post-Konrad Adenauer Germany, the state elites came to virtually double as political elites.

The makers of the Basic Law of 1949 in Germany had two dominant concerns: to safeguard the country against "the totalitarian inclinations of power-hungry political leaders" and to facilitate the stability of national government. ${ }^{12}$ Thus the Basic Law incorporated, alongside the liberal democratic principles, the view of the state as supreme arbiter of conflicting interests and guardian of the needs

\footnotetext{
${ }^{8}$ Lowell G. Nooman, France: The Politics of Continuity and Change (New York: Holt, Rinehart and Winston, 1970), 98.

${ }^{9}$ Renate Mayntz, "Executive Leadership in Germany: Dispersion of Power or 'Kanzlerdemokratie'? in Richard Rose and Ezra N. Suleiman, eds., Presidents and Prime Ministers (Washington, DC: American Enterprise Institute for Public Research, 1981), 147.

${ }^{10}$ Jean V. Poulard, "The French Double Executive and the Experience of Cohabitation," Political Science Quarterly 105 (Summer 1990): 243-267.

11 John A. Rohr, "Executive Power and Republican Principles at the Founding of the Fifth Republic," Governance 7 (April 1994): 113.

${ }^{12}$ Mayntz, "Executive Leadership in Germany," 140.
} 
of collectivity. ${ }^{13}$ This led to the emergence of the chancellor democracy in Germany. The chancellor represented the state, yet at the same time his power depended on the support he obtained from his party and the parliamentary party group (and often also from his coalition partner), as well as on his popularity with the electorate. ${ }^{14}$ German political leaders may have insisted that the citizens' first duty was toward the state, but they also acted as representatives of partisan interests. ${ }^{15}$

A similar development took place in France. The Fifth Republic, which began in 1958, was essentially based upon Michel Debre's argument that in France an institutional framework was needed as a substitute for disciplined public behavior. ${ }^{16}$ De Gaulle in turn thought that no party program could ever reflect the interests of more than a particular fraction of the French people; only a president who is genuinely above party politics can care for the common interests of all. ${ }^{17}$ The 1958 French constitution created a strong president, yet the constitution has not rendered the president unaccountable to the electorate. The French presidents have been considered chief of state and leader of France, and as such they have tried to stay above the day-to-day politics; at the same time, they have had to keep in mind their reelection. As a consequence, they could not afford to continually quarrel with their prime ministers and keep changing them - a right granted to them by the constitution. It is true that as president, de Gaulle stood rather aloof vis-à-vis the politicians and the electorate. However, Valéry Giscard d'Estaing's speeches, which were calculated to project the image of a president who looks after the French people and the French state and who at the same time is perfectly capable of engaging in partisan conflicts, reflected the behavior of post-de Gaulle presidents in France. ${ }^{18}$

\section{Unbalanced Political Development in Turkey}

Since the installation of the multiparty regime in 1945, democracy has been the only game in town in Turkey, and two mixed constitutions have been put into effect. Yet in Turkey an accommodation between the state elites and the political

\footnotetext{
${ }^{13}$ Nevil Johnson, Government in the Federal Republic of Germany: The Executive at Work (Oxford, England: Pergamon Press, 1973), 27.

${ }^{14}$ Mayntz, "Executive Leadership in Germany," 147.

${ }^{15}$ Arnold J. Heidenheimer, The Government of Germany (New York: Thomas Y. Crowell, 1971), 156.

${ }^{16}$ Anne Stevens, The Government and Politics of France (New York: St. Martin's Press, 1992), 39.

${ }^{17}$ Ibid., 61.

${ }^{18}$ Ezra N. Suleiman, "Presidential Government in France" in Rose and Suleiman, eds., Presidents and Prime Ministers, 106. Also see Jack Hayward, "From Republican Sovereign to Partisan Statesman" in Jack Hayward, ed., De Gaulle to Mitterand: Presidential Power in France (New York: New York University Press, 1993); and Harvey B. Feigenbaum, "Recent Evolution of the French Executive," Governance 3 (July 1990): 264-278.
} 
elites has not taken place. In fact, the mixed constitutions themselves have become a serious matter of contention. This is basically because in Turkey historically and during the recent decades the state elites have attempted to render the political elites into a nonentity. As a consequence, the political elites have not looked with favor on the mixed constitutions "imposed" upon them following the 19601961 and 1980-1983 military interventions.

During the nineteenth century, the representative assemblies set up in Istanbul and localities were not the upshot of demands by socioeconomic groups but the handiwork of the center itself. The motives behind their establishment were those of appeasing the Great Powers that were pressuring the Ottoman government to grant additional rights and liberties to the non-Muslims in the empire, to facilitate the collection of taxes and the recruitment to the military, and to bring limits to the sultan's prerogatives so as to make the bureaucratic elites more influential in the state affairs. ${ }^{19}$ In the Union and Progress Party period of 1909-1918, the bureaucratic and military elite members of the Committee manipulated governments from behind the scenes. ${ }^{20}$

Not much changed during the earlier decades of the Republic, proclaimed in 1923. During the single-party years of 1923-1945, the Republican People's party (RPP) was essentially an instrument of the state elites led by Atatürk and İsmet İnönü, whose primary purpose was to modernize Turkey. These state elites thought that "Islam that stood in the way of change" was the major factor in the collapse of the Ottoman Empire and attempted to educate a new generation of Turks who would think logically and who would make decisions based on reason and not religion. The republican state elites thus opted for rational democracy; for them, democracy meant enlightened debate to find out what was best for the country. ${ }^{21}$

The intellectual-bureaucratic elites schooled in the Atatürk-İnönü tradition and located in the universities, the upper reaches of the civil service, and in the ranks of the RPP attempted to keep alive the idea of rational democracy during the post-1945 multiparty politics period, too. For instance, Bahri Savc1, a professor of political science at the Faculty of Political Science of Ankara University (which for a long time served as a training ground for the bulk of the statist intellectualbureaucratic elites) made a distinction between politics in its widest sense and active dynamic politics. "Politics in its widest sense" meant determination of

\footnotetext{
${ }^{19}$ Stanford J. Shaw, "Some Aspects of the Aims and Achievements of the Nineteenth-Century Ottoman Reformers," in William P. Polk and Richard L. Chambers, eds., Beginnings of Modernization in the Middle East: The Nineteenth Century (Chicago: The University of Chicago Press, 1968); Roderic H. Davison, Reform in the Ottoman Empire, 1856-1876 (Princeton, NJ: Princeton University Press, 1963).

${ }^{20}$ Feroz Ahmad, The Young Turks: The Committee of Union and Progress in Turkish Politics, 1908-1914 (Oxford, England: Clarendon Press, 1969), chaps. 6 and 7.

${ }^{21}$ Metin Heper, The State Tradition in Turkey (Walkington, U.K.: The Eothen Press, 1985), chap. 4; on "rational democracy," we draw upon Sartori, The Theory of Democracy Revisited, Part Two: Classical Issues, 51-55.
} 
public policy based on rational analysis, though to the extent possible, coming closest to the preferences of the voters. The statist intellectual-bureaucratic elites were considered responsible for politics in its widest sense. "Active dynamic politics" referred to those activities aimed at securing and preserving political office. According to Savc1, "politics in its widest sense" had to constitute the basic framework within which "active dynamic politics" ought to have been carried on. ${ }^{22}$

The statist intellectual-bureaucratic elites' efforts to dictate to the politicians general guidelines for making policies did not go unchallenged. The new breed of politicians who claimed that they were going to represent the "national will" (milli irade) and not the state's will quickly clashed with the statist intellectualbureaucratic elites. In the 1950s, the leaders of the opposition RPP who represented the statist will heavily criticized the leaders of the Demokrat party government, who represented the "national will," for turning the rational democracy into a populistic democracy and accused them of acting against the best interests of the country. The Democrats attacked the Republicans by claiming that the Republicans were not respectful to the "national will" 23 and were in fact hatching a plot to overthrow the Democrats through a popular uprising..$^{24}$ The upshot of this irreconcilable conflict was that the statist and political elites became completely distrustful of each other and of the values the other set of elites stood for.$^{25}$

In 1960-1961, the military intervened. The statist intellectual-bureaucratic elites took this opportunity to make the "mixed" 1961 constitution that divided sovereignty between the two sets of elites in question. This constitution created the National Security Council (NSC) and the Constitutional Court, strengthened the Council of State (the Turkish version of France's Council d'Etat), and granted autonomy to the universities and the Turkish Radio and Television, in the hope they would enlighten public opinion. The rationale behind these arrangements was to bring the parliament under the virtual tutelage of the bureaucratically staffed institutions so as to establish the supremacy of the statist will over the national will.

Given the hostility of the two sets of elites toward each other, it was naive to expect the political elites to go along with this constitutional arrangement that aimed to render them into a secondary position vis-à-vis the state elites. Having always viewed the statist elites as not trying to promote the long-term interests of the community but as attempting for purely selfish reasons to prevent the political elites from having the upper hand, the political elites in Turkey have always perceived any limitation to their prerogatives as an authoritarian arrangement pure and simple and, therefore, as undemocratic. Consequently, Süleyman

${ }^{22}$ Heper, The State Tradition in Turkey, 78.

${ }^{23}$ Ibid., chaps. 4 and 5.

${ }^{24}$ Füruzan Tekil, İnönü Menderes Kavgası (Istanbul: Tekin Neşriyat, 1989).

${ }^{25}$ Metin Heper, "The Strong State as a Problem for the Consolidation of Democracy: Turkey and Germany Compared," Comparative Political Studies 25 (July 1992): 186. 
Demirel, the leader of the Justice party, a successor party to the Demokrat party, repeatedly complained as prime minister that the country could not be governed under the 1961 Constitution. ${ }^{26}$ As the basic rationale behind the notion of mixed constitution - that of obtaining prudent government alongside political participation through constitutional means when political elites are perceived not to pay adequate attention to the need for prudent government-had been alien to the political elites, ${ }^{27}$ both the Justice party and the RPP (which after 1967, under the leadership of Bülent Ecevit had lost its characteristic of being a statist party) did not hesitate to form coalition governments with such antisystem parties as the religiously oriented National Salvation party and the ultranationalist Nationalist Action party.

In the political turmoil that followed, the military intervened two more timesin 1971-1973 and 1980-1983. Following the intervention-by-memorandum of 1971-1973 (in which the military did not take power directly into its own hands but attempted to rule through an above-party government), the scope of some rights and liberties was restricted and such state institutions as the NSC were given additional authority to advise the government. During the remaining years of the 1970s, however, the political elites continued to challenge the state institutions in question and played an important role in their increasing politicization and polarization. ${ }^{28}$ Under the circumstances, the state institutions could not provide the ballast the political system needed, and the military intervened for the third time in 1980-1983.

As in the earlier instances, the military again wished to restructure the political system to make it viable through changing the constitution. The end result was the 1982 constitution in which the military junta played a far greater role than the juntas had played in the making of the 1961 constitution and in amending that constitution following the 1971-1973 intervention. Having observed "the increasing politicization and polarization of the state institutions during the previous two decades, with the exception of the [military members of the] NSC," the 1980 military intervenors perceived the salvation of democracy in Turkey in further strengthening the hand of the NSC. ${ }^{29}$ At the same time, they created a more than symbolic presidency, while maintaining parliamentarianism.

\footnotetext{
${ }^{26}$ Heper, The State Tradition in Turkey, 89.

${ }^{27}$ Metin Heper, “Turkish Democracy Reconsidered; Mlusion Breeding Disillusion” in Heiko Körner and Rasual Shams, eds., Institutional Aspects of Economic Integration of Turkey into the European Community (Hamburg: Verlag Weltarchiv G.MBH, 1990).

${ }^{28}$ C. H. Dodd, The Crisis of Turkish Democracy, enlarged second edition (Huntingdon, U.K.: The Eothen Press, 1990), 45-48. First published in 1983.

${ }^{29}$ Metin Heper, "The State, the Military and Democracy in Turkey," Jerusalem Journal of International Relations 9 (September 1987): 52-64. According to the 1982 Constitution, the Council of Ministers is obliged to "give priority consideration to the decisions of the NSC concerning the measures that it deems necessary for the preservation of the existence and independent of the state, the integrity and indivisibility of the country, and the peace and security of society" (Article 118).
} 


\section{Presidency Under the 1982 Constitution}

Despite the fact that Turkey faced a severe political instability for several decades, the political elites and the bulk of the intelligentsia continued to perceive any governmental system other than parliamentarianism as authoritarian. Under the circumstances, the only governmental system the military could come up with was parliamentarianism though with "an active and powerful president" who had "greater than normal powers" than comes across in a parliamentary system of government. ${ }^{30}$ Whereas the post- 1949 Germany had opted for a symbolic and ceremonial presidency (because the German chancellor was granted powers "greater than normal") and the post-1958 France adopted a statist and executive presidency, Turkey chose to have a statist president with limited executive powers.

Under the 1982 constitution, the governmental system in Turkey is parliamentary because the executive branch evinces a dual structure with a president who is not politically responsible. Only the Council of Ministers is responsible to the legislature. The president appoints as prime minister whomever has the majority in the parliament, and who, unlike his French counterpart, has limited influence on the composition of the Council of Ministers. The Turkish president is elected by the Turkish Grand National Assembly from among its own members.

It is a cardinal principle of the parliamentary system of government that the president is not authorized to act alone in executive matters. At first sight, the Turkish case seems to have departed from this general rule. In Turkey all presidential decrees are countersigned by the prime minister and the ministers concerned, except in those cases where he is authorized to act alone by the constitution and other laws (Article 105 of the constitution). Furthermore, the same article stipulates that "no appeal will be made to any legal authority, including the Constitutional Court with regard to the decisions and decrees signed by the president at his discretion." However, as Ergun Özbudun has shown, in no instance does the constitution explicitly specify cases where the president can act without a countersignature; either it is quite clear that the countersignature is needed or it is required because of constitutional custom. As a general rule, whenever the matter falls within the sphere of the political executive the countersignature is required. ${ }^{31}$ Özbudun has concluded that the instances in which the Turkish president can act alone normally pertain not to his capacity as "chief executive" but to his capacity as "head of state." ${ }^{32}$

Yet, under the 1982 constitution, the Turkish president's powers that he can use alone are quite numerous, which brings us to his being a statist president,

${ }^{30}$ Ergun Özbudun, “The Status of the President of the Republic under the Constitution of 1982: Presidentialism or Parliamentarism?" in Metin Heper and Ahmet Evin, eds., State, Democracy and the Military: Turkey in the 1980s (Berlin: Walter de Gruyter, 1988), 37.

${ }^{31}$ C. H. Dodd, "Political Modernization, the State, and Democracy: Approaches to the Study of Politics in Turkey" in ibid., 20.

32 Özbudun, "The Status of the President of the Republic under the Constitution of 1982," 42-43. 
though with limited executive powers. His legislative powers include addressing the parliament each year; returning bills to the parliament for reconsideration; submitting constitutional amendments to referendum; appealing to the Constitutional Court for the annulment of laws, law-amending ordinances, and the Standing Orders of the Assembly on grounds of constitutionality; and dissolving the parliament in cases specified by the constitution. Among his executive powers are those of convening and chairing the Council of Ministers whenever he deems it necessary and presiding over that Council when martial law or the state of emergency is to be declared; preparing the agenda of and chairing the meetings of the NSC; and appointing the head and the members of the State Supervisory Board (affiliated to the presidency) and instructing the Board to conduct inquiries, investigations, and inspections. ${ }^{33}$

Particularly critical among these powers is the president's preparation of the agenda and chairing the meetings of the NSC. The Council of Ministers has to give priority to the measures the NSC deems necessary for the preservation of the existence and independence of the state, the integrity and indivisibility of the country, and the peace and security of society. These are matters for which, according to the oath that he takes upon assuming office, the president is responsible. Thus, the Turkish president can use the NSC to put pressure on the Council of Ministers to take specific measures concerning those matters for which he is responsible. Also the 1982 constitution defines the duties of the president as not unlike those of the French president as stipulated by the 1958 French constitution. The Turkish constitution reads: "The president . . . shall insure the implementation of the Constitution, and the regular and harmonious functioning of the organs of State" [Article 104]. According to the French constitution, too, the president makes sure that the constitution is respected, and he insures the regular functioning of the public authorities. Both constitutions gave powers to their presidents that can be interpreted very broadly. As already mentioned, de Gaulle in France did interpret his powers very broadly; he was encouraged to do so because his duties were defined in such lofty terms. ${ }^{34}$

What differentiates the presidency in Turkey from that in France is that Turkey's office does not have the crucial legitimacy accorded by popular election. In Turkey, however, this situation is partly compensated for by the fact that in his election by the parliament, during the first two ballots the president has to obtain two-thirds of the votes; if there is a need for a third ballot, he has to have the support of the majority of the full membership. In Germany a simple majority is adequate.

This requirement of qualified majority for the election of the president by the parliament in Turkey is a means to insure the impartiality of the president which, of course, one does not come across in post-de Gaulle France. In Turkey,

\footnotetext{
${ }^{33}$ Ibid., 43.

${ }^{34}$ Douglas E. Ashford, Policy and Politics in France: Living with Uncertainty (Philadelphia: Temple University Press, 1982), $19 \mathrm{ff}$.
} 
the principle of impartiality in particular provides to the presidency a weight because, as Kemal H. Karpat has explained, the dominant philosophy in both the Ottoman and the Republican periods has been that governmental authority should be exercised strictly in conformity with the political requirement of rulership, eschewing social, economic, or ideological considerations. Power and authority could be reposed in a supreme and wise authority, which might be even a single person, so long as that person acted in the long-term interests of community. ${ }^{35}$

The impartiality of the president in Turkey is insured by other provisions, too. He is elected for a term of seven years as compared to the maximum five years of the parliamentarians. If the president-elect has been a member of a political party, he has to resign from his party. Upon his election, his membership in the parliament comes to an end. And, in contrast to the situation in both France and Germany, the president in Turkey cannot be reelected.

The impartiality of the Turkish president in Turkey gives him a special aura. His status in the polity is further reinforced by the requirements that he has to be at least 40 -years old and he must have received a university-level education. Both respect for age ${ }^{36}$ and education as a means to attain elite status ${ }^{37}$ have always been significant in Turkey. As if to underline the significance of the president in the Turkish polity, the 1982 constitution also made the impeachment of the president more difficult than the situation in both France and Germany. In France an absolute majority and in Germany a two-third majority are required; in Turkey a three-fourth majority is needed for the initiation of the impeachment process.

All in all, under the 1982 constitution, the president in Turkey has considerable clout as the guardian of the state. He is not the chief political executive, yet his responsibilities are extensive, and the fulfillment of these responsibilities may at times oblige him to transgress the political sphere. He can do this by drawing upon his morally elevated position in the polity and, in the last resort, by operating through the NSC and the State Supervisory Board. But the system of government is essentially parliamentarian, and the president has to respect the cardinal principles of that system of government, including the most important principle that the Council of Ministers has primary responsibility for determining and conducting the policy of the nation.

\section{The Dynamics of the Presidency in Post-1989 Turkey}

The first president who served under the 1982 constitution was Kenan Evren, who had been the head of the junta that had carried out the 1980-1983 military

\footnotetext{
${ }^{35}$ Kemal H. Karpat, "Military Interventions: Army-Civilian Relations in Turkey Before and After 1980" in Heper and Evin, eds., State, Democracy and the Military: Turkey in the 1980s, 152.

${ }^{36}$ Çiğdem Kağitçibaşi, "Social Norms and Authoritarianism: A Comparison of Turkish and American Adolescents," Journal of Personality and Social Psychology 16 (1970): 444-451.

${ }^{37}$ Frederick W. Frey, The Turkish Political Elite (Cambridge, MA: The MIT Press, 1965).
} 
intervention. According to a provisional article in the constitution, Evren was elected president upon the ratification of the constitution by a referendum. Particularly early in his term of presidency, he was very jealous of his prerogatives as the statist president; he displayed quite an activism with regard to such matters as terrorism, the politicization of key ministries, and the revival of Islam. At times he tended to concern himself with such matters as the Cyprus question and Turkey's relations with NATO-matters that properly belonged to the sphere of the political executive. In time, Turgut Özal, prime minister during Evren's presidency, gradually began to play a more influential role. Both Özal's circumspection while pushing Evren to his proper sphere and Evren's increasing realism about the limitations of his office led to the emergence of a division of labor and a good deal of harmony between the two of them. Özal accepted with grace Evren's suggestions and recommendations, which in turn were increasingly less frequent and harsh; for his part, Evren became more careful not to meddle in matters for which the political executive was responsible. ${ }^{38}$

The Evren presidency constituted a transitional period. His military background, his being the head of the junta that conducted the 1980-1983 military intervention, his election as president as part and parcel of the ratification of the 1982 constitution, and the never-ending barrage of criticisms directed against him by the bulk of the intelligentsia because of the above factors, could not be repeated in the following two presidencies of Özal and Demirel. It follows that the Özal and Demirel presidencies were going to constitute the real test cases for the operation of the new governmental system in Turkey - parliamentarianism with a more than symbolic presidency.

\section{Turgut Özal Presidency (1989-1993)}

Both during his prime ministry (1983-1991) and his presidency, Özal had a grandiose mission to make Turkey "one of the ten or fifteen most developed countries in the World." 39 According to Özal, Turkey had "to swim with the tide and reach the contemporary civilization." Özal thought that this mission could be achieved by pursuing "right," that is, "realistic" policies.

He argued that if one strives to come up with right policies, one cannot be criticized for acting in a partisan manner. Özal elaborated this point: he came from the bureaucracy in the late 1970s, when he was undersecretary of the State Planning Organization; bureaucratic norms reflect the state impartiality; when one has the ultimate purpose of promoting the well-being of the country, one

${ }^{38}$ For Evren presidency, see Metin Heper, "The Executive in the Third Turkish Republic, 19821989," Governance 3 (July 1990): 299-314; C. H. Dodd, “Kenan Evren as President: From Conflict to Compromise" in Metin Heper and Ahmet Evin, eds., Politics in the Third Turkish Republic (Boulder: Westview Press, 1994).

${ }^{39} \mathrm{He}$, for instance, mentioned this mission of his at the presidential oath-taking ceremony on 19 November 1989. 
would act in an impartial manner; ${ }^{40}$ in any case, just because he was president, he could not take a middle-of-the-road approach; he would go on expressing his long-held views. ${ }^{41}$

Özal, of course, had not been content with only formulating right policies; he also wanted them to be implemented by the government. He claimed that the 1982 Turkish constitution was "similar to the French one, except in a few matters like the declaration of a state of emergency." He argued that if only one sentence were added to the 1982 constitution - "The president is the chair of the Council of Ministers" - there would remain no difference between the two constitutions in respect to the powers of the president ${ }^{42}$ For a while, Özal could dictate policies to the government, because he managed to twist the arms of his former (Motherland) party's delegates, and he had a rather subservient stalwart of his, Yildirim Akbulut, elected as the leader of the party. He then appointed him as prime minister, 9 November 1989.

From the very beginning, Akbulut made it known that he would work in harmony with the president and a conflict between them would be out of the question. ${ }^{43}$ Indeed, Akbulut formed his cabinet from names suggested by Özal. ${ }^{44}$ Ôzal continued to receive regular briefings, particularly on the economy. He gave specific instructions to the government, and sometimes directly to bureaucrats.

Özal's attempt to double as prime minister attracted criticisms both from academia ${ }^{45}$ and the media. The latter began to refer to him as "Presido-Prime Minister, ${ }^{46}$ "Elected Sultan, ${ }^{47}$ and the like. Özal was undeterred. He even publicly criticized the government-if it made a critical decision without consulting him and if Özal thought the decision was not a right one. This often happened on matters concerning the economy. ${ }^{48}$ Özal also frequently meddled in the internal affairs of the Motherland party; his interest in the party was related to his activist approach vis-à-vis the economy. He said: "I myself founded the Motherland

${ }^{40}$ Cumhurbaşkanı Turgut Özal'in Türkiye'miz, Dünya ve Gelecek Konulu Konuşmaları, Ankara, 1990, booklet compiled by the President's Office, 22.

${ }^{41}$ Heper, “Turgut Özal's Presidency: Crisis and the Glimmerings of Consensus" in Heper and Evin, eds., Politics in the Third Turkish Republic, 194.

${ }^{42}$ Milliyet, (Istanbul daily), 30 November 1990. In France, the president himself can proclaim a state of emergency; in Turkey a state of emergency can only be declared by the Council of Ministers chaired by the president.

${ }^{43}$ Milliyet, 21 March 1990.

${ }^{44}$ Akbulut himself disclosed that his government was formed in this manner. Hürriyet (Istanbul daily), 30 May 1991.

${ }^{45}$ For instance, Lütfi Duran, “Türk Anayasası ve Fransa Örneği," Cumhuriyet (Istanbul daily), 13 December 1990.

${ }^{46}$ Columnist Derya Sazak in Milliyet, 3 March 1990.

${ }^{47}$ Editorial in Hürriyet, 30 November 1990.

${ }^{48}$ For examples of such criticisms directed to the government by Özal, see Cumhurbaşkanı Turgut Özalin Türkiye Tarım Kredi Kooperatifleri Merkez Birliği Genel Kurulındaki Konuşmalarn, Ankara, 1990, 18; Dünya'daki Dengeler ve Türkiye, Ankara, 1991, 23-23; Geleceğe Bakıs, Ankara, 1992, 2730, all booklets compiled by the President's Office. 
Party. . . . We made certain promises to the people. . . . As today's government has no independent program of its own, it is my duty to warn the government if it acts contrary to the program it adopted intact. ${ }^{.49}$ On foreign policy issues, Özal took the initiative and acted alone. He disclosed his views on sensitive foreign policy issues and negotiated on critical problems with other countries without even consulting the Ministry of Foreign Affairs. ${ }^{50} \mathrm{He}$ justified such conduct by noting that as president and head of the NSC he was responsible for the external security of the country. ${ }^{51}$

When in June 1991 the term of Akbulut's party leadership came to an end, Özal again tried to influence the outcome of the election of the next leader of the party at the party convention. This time, however, he was not successful, and his former Minister of Foreign Affairs Mesut Yllmaz, with whom he did not look eye to eye and who was not prepared to be Özal's loyal servant, was elected. When Yllmaz became prime minister, he wanted to have cordial relations with Özal, but not to conduct his ministry under his shadow. Yılmaz pointed out that Özal was the spiritual leader of the Motherland party, but added that he and his colleagues in the party would carry out their relations with Özal "within the parameters set by the Constitution." 52

To Özal such a relationship with the prime minister was, of course, not satisfactory. Furthermore, by this time Özal had come to the conclusion that "his" party had begun to shed its earlier reformist approach. Consequently he wished to give direction not only to the government but to the party. And he continued to invite some ministers and key bureaucrats to the Presidential Palace to be briefed by them. This led to Yllmaz's asking ministers and bureaucrats not to see the president without first obtaining his permission.

But Özal did not give in easily. He argued that he was interested neither in the day-to-day operation of the government nor in party business but in policy issues. He did not want policies that had "contributed to the Motherland success in the past" to be abandoned. However, Yllmaz was adamant in maintaining the autonomy of both the government and the party from Özal. Y1lmaz even implicitly threatened Özal by saying that if Özal would not intervene in the party affairs his presidency would become less debatable.$^{53}$ Here Yllmaz was drawing attention to the fact that because Özal's election to the presidency had led to debates concerning the legitimacy of his presidency, Özal needed the support of the Motherland party, of which Yllmaz was the leader. Upon these developments, Özal discontinued his weekly meetings with Yllmaz. For the rest of Yllmaz's ministry, the relations between him and Özal remained rather cool.

On 20 October 1991, Turkey had new general elections. The Motherland party came second behind Süleyman Demirel's True Path party. The new govern-

\footnotetext{
${ }^{49}$ Reported in Türkiye'miz, Dünya ve Gelecek, 40-41.

50 Among others, see Cumhuriyet, 1 January 1990; Milliyet 28 March 1990.

51 Turkish Daily News (Ankara daily), 15 March 1990.

52 Hürriyet, 4 July 1991.

53 Milliyet, 15 August 1992.
} 
ment was formed by the True Path party and the Social Democratic Populist party, and Demirel became prime minister.

In the past, Özal and Demirel had had rather tense relations. Demirel always thought that Özal had acted in an opportunistic manner following the reinstallation of democracy in 1982, because "Özal had formed the Motherland party" and stole the votes of Demirel's old Justice party in the 1983 general elections. At the time, Demirel was banned from politics. Furthermore, when the issue of the return of Demirel's and other such pre-1980 politicians' political rights through a referendum came to the agenda, Özal campaigned against such a move. In return, when Özal was elected president on 26 September 1989 by the votes of the Motherland party, which at the time was thought not to have behind it the support of the electorate, Demirel along with others argued that Özal's presidency was not legitimate and promised to bring him down by amending the constitution as soon as he could control the necessary number of votes in the parliament.

Initially it seemed as if the president and the new prime minister would get along well. In a surprise move, Ôzal stated that his era had come to an end: during the 1987 election campaign, as prime minister, he had made certain promises to the people; he had a moral responsibility to make good on those promises; but there had been new elections; now those who have just obtained a mandate from the people would rule. Özal added that he would go on expressing his views, but it was up to future governments whether to take them into account or not..$^{54}$ In his turn, Demirel indicated that he would let bygones be bygones, because the "smooth functioning of the state" was important. ${ }^{55}$ Yet Demirel, not unlike Yllmaz before him, felt the urge to remind Özal that "the president is head of the State but not of the political executive. The president's powers have been clearly indicated in the Constitution . . . . The duty of the president is only that of coordination. ${ }^{56}$

Despite this reminder from Demirel and despite what he had said earlier about his era having come to an end, Özal wished that his weekly meetings with Demirel should be with an agenda,$^{57}$ so that he could participate in the governmental decision making. When Demirel did not comply, Özal declined to sign governmental decrees about appointments to some bureaucratic posts. He said that reshuffling of top bureaucrats had been informed by partisan considerations. He argued that governments might change but there were some things that should remain the same. ${ }^{58}$ Özal again invited bureaucrats to the Presidential Palace and wanted to be briefed on the economy. He also created his own staff of experts, which he used to come up with alternative policies. He earnestly

\footnotetext{
${ }^{54}$ Heper, "Turgut Özal's Presidency: Crisis and the Glimmerings of Consensus" in Heper and Evin, eds., Politics in the Third Turkish Republic, 197.

${ }^{55}$ Cumhuriyet, 4 January 1992.

56 Ibid., 31 January 1991.

${ }^{57}$ Ibid., 1 January 1992.

58 Milliyet, 7 January 1992.
} 
hoped that the Demirel government would make use of his expertise. When this was not done, Özal began to openly criticize the government and to appeal directly to the people. He also urged the Motherland party to conduct a more active opposition and even suggested to the party specific tactics for this purpose.

All of these efforts on his part were of no avail. Demirel's position was that there was no need for him to meet with the president on a weekly basis. He would meet with Özal when there was a need. When asked, the government would not refuse to give information to the president, but again there was no need to do this regularly. Demirel even refrained from providing Özal with background information about the appointments he wanted to make in the bureaucracy, because he was unwilling to "negotiate" such matters with the president. ${ }^{59}$ Demirel did not want to create a "coalition partner in the Presidential Palace."

Özal received a cold shoulder for the Yilmaz's Motherland party, too. As earlier, Yılmaz again did not want Özal to exercise control over the party. In fact, Özal and Yılmaz had diametrically opposite views on this issue. Özal thought that because Yulmaz did not pay attention to his views, the Motherland party had constantly lost ground in Turkish politics. ${ }^{61}$ Yllmaz in turn had been of the opinion that if he acted along the lines Özal suggested he could not have been an effective leader. ${ }^{62}$

All this made Özal quite a dejected man. He even started toying with the idea of resigning from the presidency, forming a new political party, and realizing his Second Transformation program. ${ }^{63}$ At this juncture he suddenly died of a heart attack on 17 April 1993.

\section{Süleyman Demirel Presidency (1993-1996)}

Demirel followed Özal in the presidency on 16 May 1993. Initially, Demirel did not know how to conduct his presidency. He indicated that he was endeavoring to interpret the constitution and set his own style as president, ${ }^{64}$ just as Özal had done.

Just as Özal, Demirel had a vision of a stable democracy, a stable economy, and a strong army.$^{65}$ Unlike Özal, however, Demirel placed emphasis on political stability rather than change. Political stability was dependent, according to Demirel, first and foremost on "democratic authority" and "rule of law." Democratic authority meant the autonomy of political institutions from politically nonaccountable institutions. Here, he particularly had in mind the military. In the past he had twice been ousted from power by the military, in 1971 and 1980.

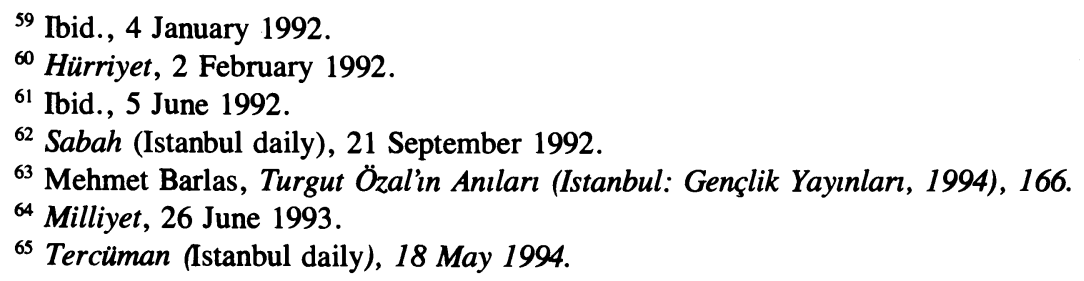


Demirel placed emphasis on rule of law also because he did not want his presidency to be debatable like that of Özal ${ }^{66} \mathrm{He}$ said: "The President of the Turkish Republic will be a Constitutional President. He will not use powers that the Constitution has not granted him. . . . If all institutions remain within their constitutionally defined powers then democratic authority will be set up and there will be democratic stability. ${ }^{.67}$ Whenever he indicated which political institution was responsible for what function, he always added, "There are rules in this country; everybody should conform to those rules ${ }^{68}$ For Demirel, political stability was dependent upon each institution satisfactorily performing its functions. He thought that when necessary he should contribute to the satisfactory performance of functions by institutions, without, however, dictating policies to those institutions.

Thus Demirel was of the opinion that his primary function as president was that of insuring "the smooth functioning of the state." ${ }^{\prime 69}$ Therefore, he concluded that, among other things, he should sign decrees about appointments made by the government without making any fuss about them and should not in principle resort to his constitutionally granted delaying powers in respect to legislation, even if "the latter had some debatable points." When at some point he was asked to take initiative and urge the Council of Ministers to declare a state of emergency on account of serious economic crisis, Demirel said that the economy was not his direct responsibility. ${ }^{71}$ Similarly, when his assistance was sought to remove the government from power he indicated that it was a responsibility that belonged to the parliament. ${ }^{72}$ In this spirit, Demirel even pointed out that the National Security Council was a constitutional institution and had been fulfilling its responsibilities in accordance with the constitution. ${ }^{73}$ Demirel made this statement when some pundits had made a distinction between the military and the civilian solution to the Kurdish issue in Turkey and denounced the military solution-crushing the terror and then bringing further socioeconomic development to the area versus the civilian solution of extending political and cultural rights while the separatist terror continued unabated.

On the other hand, Demirel has been enthusiastic about using some of his powers as head of state in a guarded manner. For instance, he insisted that he had discretion on whether to approve or disapprove the candidate for chief of the general staff nominated by the government. He had his way. ${ }^{74}$ Similarly, he

\footnotetext{
${ }^{66}$ Milliyet, 17 May 1993.

${ }^{67}$ Cumhuriyet, 15 May 1993. Since Demirel had fiercely criticized Özal of having transgressed his powers, he was now being too careful regarding this matter.

${ }^{68}$ For one such statement, see Sabah, 5 December 1993.

${ }^{69}$ Abdullah Uraz, Millet Devlet Kucaklaşması (Ankara: Eka, 1994), 74-116.

70 Türkiye (Istanbul daily), 22 May 1994 and his press conference on 16 May 1994.

71 Sabah, 5 April 1994; Hürriyet, 2 February 1994.

72 Meydan (Istanbul daily), 9 May 1994.

${ }^{73}$ Sabah, 13 November 1994.

${ }^{74}$ Hürriyet, 6 May 1994.
} 
pointed out that the separatist terror in southeastern Turkey was not a matter of the government but for the state. Yet he did not become directly involved in this issue. He met with the leaders of the opposition parties, conveyed their views on the issue to the prime minister, and thought he accomplished "his duty of coordination." $" 75$

Demirel's willingness to contribute to the success of the institutions without interfering in the way they conducted their business came out quite clearly in his relations with his former political party, the True Path party, which has been the senior partner of the present coalition government both during his prime ministry (1991-1993) and his presidency, and in his relations with the government led by Tansu Çiller. Before he became president, Demirel had promised that he would not meddle in party affairs. ${ }^{76}$ There is no hard evidence that he did not keep his word. He also seems not to have actively interfered in the election by the party of Tansu Çiller as the new leader of the party.

Demirel, however, allowed members of the opposition to visit him and complain that Çiller and the politicians in her close entourage were acting contrary to the traditional goals and policies of the party. It has been reported that on such occasions Demirel advised members of the party to work for the success of the party. ${ }^{77}$ Demirel explained his behavior as follows: his basic concern is the stability of the political system. Stability within political parties, including his former party, contributes to the stability of the political system as a whole. Also, the success of the party in government would increase the trust of the citizen toward the regime. Impartiality means that one does not meddle in the affairs of a political party continuously; if one involves oneself in the affairs of a political party once in a while and if one does that for a larger purpose, one cannot be considered as acting in a partisan manner. ${ }^{78}$

Demirel had in general a guarded approach concerning his relations with the government, too. For instance, despite some persistent questions from journalists, on the whole, he avoided disclosing what he thought about the performance of the government. Only on rare occasions did he somewhat show his hand when he said things like, "it is not my business to attribute fault to anybody" 79 or "the president should not act like the leader of the opposition." ${ }^{80}$ Still, even on those occasions Demirel considered the presidency as a "place of arbitration." When the president becomes involved in political issues, Demirel thought, he should act in an objective manner and for the benefit of the whole country. ${ }^{81}$ Demirel pointed out that here "political" means "Turkey's problems," ${ }^{\prime 2}$ that is, vital prob-

${ }^{75}$ Milliyet, 21 October 1993.

${ }^{76}$ Cumhuriyet, 16 May 1993.

${ }^{77}$ Hürriyet, 25 September 1993 and 21 February 1994.

${ }^{78}$ Sabah, 20 December 1993; Milliyet, 27 June 1993; Hürriyet, 22 December 1993.

${ }^{79}$ Sabah, 5 May 1994.

${ }^{80}$ Milliyet, 16 May 1994.

${ }^{81}$ Ibid., 27 June 1993; also see Uraz, Millet Devlet Kucaklaşması, 199, 276.

${ }^{82}$ Hürriyet, 11 August 1993. 
lems of the country. He has been of the opinion that he should always be consulted on "Turkey's problems." Demirel has pointed out that the Turkish political system is not like the German political system; it is more like the French political system: "The Turkish presidency is not a post where, concerning Turkey's problems, one can say 'I do not care." ${ }^{83} \mathrm{He}$ added: "I do not give directives, but what I say is more than advice. If what I think is not right then they should tell me why I am not right;" 84 "I am not trying to substitute for them; I am telling them that there is a critical problem which should be attended to in a particular manner." ${ }^{85}$

On rare occasions, however, Demirel went out of his way and openly criticized the government. He pointed out that he acted in the said manner when Turkey faced an important problem and the government was not paying attention to his views. If a matter were of vital importance, such as a religiously oriented party capturing government and trying to turn the clock back in Turkey, Demirel felt the need to draw the line once and for all: "The government is one of the organs of the state which is not just a sum of different institutions. One does not become a king just because one is elected. There is the Constitutional Court and the Presidential Palace. In this country, one cannot do whatever one fancies. ${ }^{" 86}$ Thus, in some isolated cases, Demirel did transgress the government's prerogatives, though rather timidly.

\section{CONCLUSION}

As Giovanni Sartori has argued, a viable democracy is dependent upon a judicious blend of political participation and prudent government. In some contexts, politically accountable elites play a key role in achieving both. In other contexts, the responsibility of providing a prudent government is undertaken by politically unaccountable elites. In such countries as France and Germany, the situation of a polity functioning under a mixed constitution does not prove problematic, because in those countries the need for such a political arrangement is recognized by the major political actors, who do not challenge that arrangement. There is a near consensus on what is needed, the making of the relevant political arrangement is not half-hearted, and the outcome to a great extent fulfills the need. Political institutionalization a la Samuel Huntington is achieved through a mixed constitution; the politically nonaccountable elites provided the ballast that the system needed from time to time.

In Turkey, historically and in some periods during the recent decades, the politically less-than-accountable elites dominated the political scene. Following the installation of multiparty politics in the 1940s, the new category of political elites, Democrats, placed emphasis on political participation with strong doses

\footnotetext{
${ }^{83}$ Ibid.

${ }^{84}$ Milliyet, 24 May 1994.

${ }^{85}$ Ibid., 12 July 1993.

${ }^{86}$ Meydan, 15 June 1994.
} 
of populism and, on the whole, gave short shrift to prudent government. They did this basically out of hostility toward the statist elites' earlier domination of the political scene. This led the statist elites to think that political elites ignored the long-term interests of community. As a consequence, the statist elites tried to achieve Huntingtonian political institutionalization by forging the mixed constitution of 1961. In essence, parliamentarianism was retained, but parliament was brought under the surveillance of a number of bureaucratic agencies. Democrats dubbed that political arrangement as undemocratic. Political crises that followed ultimately led to the 1980 military intervention and to Turkey's second mixed constitution of 1982 .

The 1982 constitution retained the parliamentary nature of the regime but gave more than normal powers to the president. Such provisions as his being elected by a qualified majority, his nonelection, the difficulty of his being impeached, and the like accorded the president a certain amount of weight in the polity. Yet he lacked the crucial legitimacy that derives from being elected popularly. In the absence of such legitimacy, his relations with the political executive were defined in a rather ambiguous manner, which made it difficult for the president to provide the guidance the system might have needed from time to time and to accomplish this in such a way that the constitutionality of his actions would not become debatable.

It could have been a miracle if under the Özal and the Demirel presidencies the political system had functioned in a manner close to the constitutional system, hesitantly and half-heartedly put together because of the continuing lack of appreciation by the political actors for Huntingtonian political institutionalization. Özal wanted to dominate the political system and resorted to a one-man show. As the nominal head of the political executive, he attempted to dictate policies to governments. Except for a brief period during which a politician completely subservient to him occupied the prime ministry, Özal's actions as head of state attracted heavy criticisms from all quarters, and gradually he became relatively timid as head of state. Özal first tried to attribute to himself powers greater than those he actually had as head of state; when this did not work, he became hesitant to use the powers he actually had. Özal essentially wanted to function as a political executive rather than as head of state; he was interested in contributing to public policy making rather than adopting a longer view. His activist stance drew reaction; consequently, he could not even contribute to public policy making. His activist approach created tensions in the polity.

Demirel has displayed a different presidential style. From the very beginning, he has been very cautious as head of state; he thought his responsibility consisted only of achieving coordination among different state organs as well as political parties. He was somewhat less timid in his relations with the political executive; on occasions he insisted that the latter pay close attention to his views. When the political executive did not pay attention to him, he publicly criticized him, giving rise to some tension in the polity. 
Given the past political developments, the parliamentary system of government with a more than symbolic president proved to be rather problematic in Turkey. Turkish political actors could not appreciate the need for this type of political structuring. First, they continued to have their old agendas and to try to settle their old scores. Second, in the absence of the institutionalization of the new political regime in Huntingtonian lines, their mode of operation was shaped by their own preferences and prejudices. Özal tried to accomplish his grandiose mission of transforming Turkey; Demirel wanted to operate within the strict limits of rules and regulations, because in the past the military had transgressed civilian governments' powers. In the process, the idea of a mixed constitution remained alien to Turkish political actors, and politics continued to experience tensions that made prudent government difficult.

It is patent that the Anglo-American pattern of achieving a balance between political participation and prudent government is more democratic than any other arrangement and leads to a more harmonious polity. A polity functioning under a mixed constitution is a second best arrangement. When the political elites are not able to contribute to achieving prudent government in a satisfactory manner, the latter type of political structure contributes to prudent government. Given the fact that the transition to democracy in Turkey was characterized by an intense conflict between the political and the statist elites and in the process political elites tended toward a populistic understanding of politics, there was a need for a polity functioning under a mixed constitution. Although the conflict in Turkey between the two sets of elites made a harmonious operation of the polity under a mixed constitution extremely difficult, because of a basic commitment to democracy on the part of nearly all actors in the polity, the failure of the arrangement in question has not resulted in the establishment of a long-lasting authoritarian system of government. But it was unfortunate for Turkey that the two attempts at adopting mixed constitutions ended in failure, and the Turkish political system was deprived of the contribution that capable presidents could make to prudent government.

In the absence of such a contribution by presidents, would officers be tempted for another military intervention if they think that Turkey faces a grave threat of some sort? Since their last intervention in 1980, the military seems to have arrived at the conclusion that a coup is not a feasible way of consolidating democracy and that each intervention leads to the military's loss of prestige, particularly among the intelligentsia. ${ }^{87}$ In any case, the military can make its views known to the government constitutionally through the National Security Council. The military gradually came to have a civilian ethic and accepted the supremacy of the political government. ${ }^{88}$ Still, some pundits in Turkey speculate that the military may still step in if the regime is threatened by militant Islam or the ethnic right.

${ }^{87}$ Ahmet Evin, "Demilitarization and Civilization of the Regime" in Heper and Evin, eds., Politics in the Third Turkish Republic, 23-40.

${ }^{88}$ Hale, Turkish Politics and the Military. 
At this point there is no politically efficacious ethnic right movement in Turkey that may develop into a parliamentary majority. There is, however, an Islamic movement that registered considerable success in recent municipal elections and that has a political party, Prosperity party (Refah Partisi), which in June 1996 became the senior member of a governing bloc in parliament. Refahis are not equivocal whether they aim at an Islamic state or would be content with the incorporation of some religious demands into public policy making. If they do not try to bring about an Islamic state, the military in all likelihood will not intervene.

The Refahis developing into a greater political force to be reckoned with largely depends, it is thought by many in Turkey, upon the secular political parties. Adoption of a run-off election system, for instance, would successfully bar the Prosperitarians from power, because presently the votes of the secular bloc are badly divided. So far, secular political parties on the left or the right (which are bigger) could not cooperate among themselves in order to ward off a religious threat to the regime.

The parties on the right, which have been garnering most of the votes in the recent past, always thought that in the future elections, they will come out on top with the Prosperity party far behind. The president remains silent on the issue. The military command is careful not to make any overt political statements. It follows that the 1982 mixed constitution does not function. Warnings for an imminent Islamic threat to the regime come from journalists and other members of the intelligentsia. So far these warnings have failed to elicit any positive response from the political parties in the essentially secular bloc. This complacency may be due to the fact that the military continues to be staunchly secular and that it constitutes a safety valve against development of an Islamic state. If our prognosis has validity, we face a peculiar situation: many members of the secular bloc who think of themselves as true democrats bypass the presidency and perhaps unconsciously rely upon the military to deal with a possible threat against the regime, when the military itself is most unwilling to get entangled once more in the quagmire of the day-to-day politics in Turkey.

Turkish parliamentarianism continues to suffer from its past political legacies. Nevertheless, at least for the members of the secular bloc, democracy continues to be the only game in town. But it needs to be complemented by prudent government. Turkish politicians should either double as statist elites or acknowledge the need for a polity operating under a mixed constitution. The first option is more desirable. 